\title{
HIRA wt Allele
}

National Cancer Institute

\section{Source}

National Cancer Institute. HIRA wt Allele. NCI Thesaurus. Code C75508.

Human HIRA wild-type allele is located in the vicinity of 22 q11.2 or $22 q 11.21$ and is approximately $101 \mathrm{~kb}$ in length. This allele, which encodes protein HIRA, is involved in the modulation of chromatin structure. Haploinsufficiency of the gene may be a factor in DiGeorge syndrome. 